\title{
The Role of Manufacturing Industrial Activity in the Environmental Pollution in South Sulawesi
}

\author{
Tri Astuti \\ Hasanuddin University, Makassar, Indonesia \\ astutijaudin@yahoo.co.id
}

\begin{abstract}
Deteriorating environmental conditions can be a hindrance in creating a sustainable economic development so that necessary concern of all parties. The study aims to identify the industrial sectors causing the heaviest pollution and to confirm the environmental economic theories applicable to the condition in South Sulawesi. The study objects are the economic activities in South Sulawesi as summarized in the I-O table transactions. The data used are secondary data of the income per capita and of environmental pollution, table I-0 of South Sulawesi in 2010, and the IPPS standard of pollution intensity estimate, and cost coefficient for pollution eradication. The tools used are conventional input-output, environmental input-output, and trend analyses. The reveals that the chemical and metal manufacturing industry sectors are the primary causes of severe pollution in South Sulawesi in 2010 and the environmental economic cases tend to comply with Hypothesis Haven. This research is an academic study limited only to investigate the role of economic activities in industrial manufacturing sector so that further study can be foccused on the role of the whole activities of the economic sector in the environmental pollution.
\end{abstract}

Keywords: Key sector, environmental input-output, pollution, hypothesis haven, hypothesis porter

\section{Introduction}

The development of industrial sector is a top priority in the development plan of developing countries (NSB). This happens because the industrial sector is regarded as the leading sector that is able to encourage the development of other sectors, such as services and agriculture sectors, (Arsyad, 2010). Ragnar Nurkse stated that the vicious circle of poverty in developing countries will decelerate their economic development. Therefore, if they want to accelerate their economic growth then the vicious circle must be stopped by doing simultaneous and massive capital investments in the interrelated industries and creating markets for their products (Razak, 2009). The effort in developing industrial sector has been popular after World War II. It is pioneered by Perroux, Myrdal, and Hirschman. Perroux theory known as the term of center of growth (Growth Pole) is a theory used as the basis of the policy strategy of regional industry development that are widely applied in various countries today. National development activities tend to be oriented on an economic growth. However, the source of economic growth is still relying on the use of natural resources. Industrial activities and the use of natural resources occurring continuously will cause negative externalities for the environment in the form of pollution and environmental damage. According to Suparmoko and Suparmoko (2000), externalities occur by which people's activity impacts to others, whether benefits or external costs that require no obligation to receive or to pay it.

At the present, the impact of environmental degradation and pollution has been in the adverse conditions and interfering human life, such as acid rain, drought, global warming, and climate change. The most noticeably impact is by flood and landslide in the various regions. Thus, the high economic growth is in fact paid expensively with increasing pollution and environmental damage. This deteriorating environmental condition can be an obstacle in creating a sustainable economic development. It is therefore necessary to adopt policies that control the negative externalities such as pollution from economic activities without having too much sacrifice of the economic activity. In this case, the attention of all parties is required, both government and society upon the environmental conditions in the national development. Rukmana (2012) stated that the economic approach is one of approaches that can be used to overcome the problem of natural resources scarcity and environmental degradation. The relation between economic growth and environmental pollution is implied in the pattern of relation which is known as the Environmental Kuznets Curve (EKC). Kuznets curve concept was used by Grossman, \& Krueger (1991) to explain the pattern of the relation between environmental quality measurements with income per capita. Their research proved that the relation pattern between the level of environmental degradation and per capita income follows an 
inverted U pattern as the pattern of the relationship between inequalities of income with the Kuznets's curve.

There are two hypotheses related to the implementation of environmental policy. Birdsall and Wheeler (1993) put forward the hypothesis haven (The Pollution Haven Hypothesis), while Porter and Der Linde (1995) put forward Hypothesis Porter. Several empirical studies related to use of I-O Environment as analytical equipment referenced in this research are: Hussein (2007), Herman (2007), Handayani (2006), Kurniati (2005), and Resosudarmo (2000). Judging the magnitude of the environmental damage phenomenon which is caused by the construction activities, the researcher interested in conducting research on the role of Manufacturing Sector Activity against Environmental Pollution in South Sulawesi.

\section{Literature Review}

The Role of the Industrial Sector in Development: The role of the industrial sector in economic development can be traced from the contribution of each sub-sector to the economic growth rate or to the national income. In addition, for certain areas, either the district, or province can also be done by looking at the amount of investment that is issued to the sector and see its effect on revenue (PAD). The attention to the new industrial development efforts popular after the World War II. The effort is spearheaded by Perroux (1970), Myrdal (1957), and Hirschman (1958). Perroux's theory known as the center of growth (Growth Pole) is a theory that became the basis for the strategy of regional industrial development policies that are widely applied in various countries today. In the view of Perroux, growth will not appear in various areas at the same time. Growth only occurs in some place called growth centers with different intensities.

Linkages among Industries: At the beginning of the industrialization policy, economists advocate successfully demonstrated that the industrial sector is the leading sector, because the industrial sector is considered able to stimulate and encourage investment in other sectors. But today, the pattern of industrial development shows about the relation, both linkages in the industry itself (internal linkage) and the linkages between industry and other sectors (external linkage) so that the industry needs to be developed. The linkage between economic sectors can be seen through the total index linkage. This index is used as a basis for the formulation of an economic development strategy. According to Rasmussen total index linkage includes a total of backward linkages index which indicates the spread and forward linkages total index, which indicates the degree of sensitivity.

Economic Relations and The Environment: Rukmana (2012) stated that the economic approach is one approach that can be used to address the problem of scarcity of natural resources and environmental degradation. The basic premise of the concept of the economic approach is that the price change would cause consumers and producers to change the behavior of consumption and production. Economic approach can integrate environmental considerations into economic policies that encourage the implementation of the principles of sustainable development and improve the quality of life .

Growth and Pollution: The relationship between economic growth and environmental pollution, implicit in the pattern of relationships which came to be known as the Environmental Kuznets Curve (EKC). EKC concept used Grossman \& Krueger (1995) derived from the concept of the Kuznets curve that links between economic growth and income inequality. Kuznets curve concept used by Grossman and Krueger to explain the pattern of the relationship between environmental quality measurements with income per capita. Grossman and Krueger study proves that the shape of the relationship between the level of environmental degradation and income per capita follow an inverted U shape pattern as the pattern of the relationship between income inequality by income per capita in the Kuznets curve. Research Shafik (1994) also reported similar results.

Economic Growth and Environmental Quality: Birdsall, Nancy and Wheeler, David (1993) says that when the regulation of higher environmental standards applied in a country, the large multinational corporations in the country probably contributed to its implementation, in order to reduce the profits of local companies that are smaller. This effect creates a country with harsh environmental standards become a refuge for large company. Smaller firms are more likely as an agent of pollution compared to large multinational companies, as theorized as the Pollution Haven Hypothesis. While the second hypothesis, namely Porter 's Hypothesis stated otherwise. Porter, Michael E. And Claas van Der Linde (1995) believes that the existence of the regulation will lead to innovation to improve the competitiveness of the company and offset the environmental costs. According to Porter, the existence of the regulation will create pressure 
to motivate companies to innovate and various kinds of advances in the use of resources efficiently and always make technical improvements to reduce the costs of environmental control.

Definition and Measurement Externalities: According Suparmoko and Suparmoko (2000), externalities occur when a person performs an activity that impacts to others, either benefits or external costs that do not require the obligation to receive or pay. The existence of externalities that are not taken into account the cause decision makers or managers are not appropriate policies and activities carried out inefficient. Therefore, the costs and benefits externalities of each sector of the economy need to be internalized by calculating the impact of its activities on natural resources and the environment.

\section{Methodology}

Location and Research Design: The research was conducted in South Sulawesi on June until July 2013 by using quantitative approach. The determination of the research location is done under the consideration of South Sulawesi is one of the highest ten economic developing rates in Indonesia. The discussion in this study is limited to the role of the manufacturing sector activity against environmental pollution. Environmental pollution in this study is limited to air and water pollution of a river by using the parameters of NO2, SO2, TSP, BOD, and TSS. The hypothesis of this study were: 1) The highest polluter for environmental pollution in South Sulawesi is the processing industrial sectors which are becoming a key sector of the economy, and 2) Environmental issues in South Sulawesi tend to close to the Hypothesis Porter

Data Collecting Methods: As the analysis requirements, this study uses secondary data which are per capita income and Table I-O of South Sulawesi in 2010 from the Central Statistics Agency (BPS), the data of chemical industry, agro and forest products of the Department of Industry and Trade of South Sulawesi province, and the data of environment from the Regional Environmental Agency (BLHD) South Sulawesi Province. In addition, there is also the collecting data of the damaged biophysical environment such as; air and river pollution which is caused by the activity of various economic sectors in South Sulawesi. Types of air pollutants used in this study were sulfur dioxide (SO2), Nitrogen Dioxide (NO2), and Total Suspended particulates (TSP), while the river water pollutant used were Biological Oxygen Demand (BOD) and Total Suspended Solid (TSS). Meanwhile, the supporting data in estimating pollution and cleaning cost were obtained from the standard conversion of Industrial Pollution Projection System (IPPS) World Bank.

\section{Data Analysis Methods}

Conventional Input-Output Analysis: The basic framework of input-output analysis is a form of the dependence relation analysis among economic sectors in an economic system within a certain time period (one year), and the economy is in a stable condition. The Linkage between economy sectors can be seen through the total of index linkage to the front and to the rear, in that to obtain the key sectors of the economy of a region.

Environmental Input-Output Analysis: Because of its ability to show the linkage of various sectors in an economic system, the Input Output analysis is developed for the more specialized use which analyzing the interaction between economic activities and the environment through internalizing the environmental burden as columns and rows deduction of input-output coefficient matrix (Miller and Blair, 1985). Resosudarmo (2000) have modified the I-O Environmental Table for Indonesia, which was done by putting pollution variables and variable costs of pollution cleaning in the line $n+1$ (outside the system matrix of the flow of goods / services across sectors), where $\mathrm{n}$ is the number of sectors. In this case, pollution and cleaning costs are considered as additional value (primary input), but in terms of negative additional value (negative externalities). Based on this environmental input-output, the researcher can do some calculations, namely: 1) Pollution effect and Pollution effect index 2) Multiplier Pollution and Multiplier Pollution Index, 3) Effect of cleaning costs and effect of cleaning Cost index, 4) Multiplier Cleaning Costs and Index Cleaning Cost multiplier, and 5) Pollution cleaning effectiveness Index and Pollution Prevention Effectiveness Index.

Trend analysis: Trend is a movement of fluctuation tendency in the long term derived from the average change over the time and the value is quite flat (smooth). To address concerns about environmental economic theory applied in South Sulawesi, firstly the researcher performed a trend analysis on the 
Environmental Kuznets Curve (EKC) which is found in South Sulawesi. Then the discussion is associated with the possibility of the enactment of hypotheses haven or hypotheses porter.

\section{Results}

The result of calculation of the total index forward and backward linkage shows that the sectors of the wood processing industry (excluding furniture), non-metallic mineral processing, and transport and communication sector have the forward and backward linkage total index which is greater than one. This means that these sectors have a strong link with the upstream and downstream sectors, which is why an increasing / decreasing output in these sectors will greatly affect the increasing / decreasing economic output in South Sulawesi. Therefore, these three sectors are considerable as the key sectors of economy, as summarized in Table 1. . The Summary of the calculation result of input-output analysis environment of South Sulawesi in 2010 is shown in Table 2. Base on the Table 2, the highest pollution effects on sectors ranges from the chemical processing industry, rubber, and plastics, basic metals and metal goods processing. This means that these manufacturing sectors are the heaviest polluters in South Sulawesi in 2010. Based on the results of the pollution effect index calculation, the pollution multiplier index, the cleaning cost effect index, and the cost multiplier index, it is known that the textile manufacturing industry, apparel, and leather are the only manufacturing industry sectors which have the forth of less than one index values. It means that these sectors are safe for the air and water environments in South Sulawesi in 2010. Based on the calculation of pollution cleaning effectiveness index, it is obtained the greater than one index value in the industrial sector of furniture processing. It means that the furniture industry is a relative sector of environmental pollution, but the required cleaning cost is relatively inexpensive. The Calculation of Pollution prevention effectiveness index produces index value in greater than one basic metal and metal goods processing industry. It means that these manufacturing sectors causing severe pollution to the environment in South Sulawesi and relatively in expensive cleaning costs. The value of environmental pollution that occurred in South Sulawesi as shown in Table 3 measured from the amount of pollution cleaning costs is IDR 278.28 billion, or it is equivalent to 2.8 percent of total output of the manufacturing sector. Results summary of the trend analysis can be seen in Figure 1. Based on Figure 1, the environmental pollution in South Sulawesi has increased along with the increasing of income per capita, but the trend of diminishing returns.

Discussion: The result of analysis on Table 1 shows that the key sectors of the economy in South Sulawesi in 2010 are the wood processing industry (excluding furniture), non-metallic mineral processing industry, and transport and communications sectors. With the limitation of this research on the manufacturing sector, the wood processing industry (excluding furniture) and non-metallic mineral processing industries are the two processing industrial sectors which become a key sector of the economy of South Sulawesi in 2010. As a key sector, these two processing industries have a very meaningful influence upon other sectors. Thus these two sectors will affect the growth of both upstream and downstream sectors. The increase or decrease in the production of these two sectors will affect both the increase and decrease of output in the economy of South Sulawesi. In addition, becoming a key sector, wood processing industry (excluding furniture) is also the most prominent and largest output value for GDP Regency / City in 2010 in Bulukumba (IDR 32.55 billion), Jeneponto (IDR 17.35 billion), and northern Luwuk (IDR 154.44 billion). Whereas, the non-metallic minerals manufacturing sector provided the greatest output value in Pangkep district with a production value of IDR 2.79 trillion in 2010 .

It is also seen that there are eight sectors that have strong backward linkages. The construction sector is in the strongest position as a sector that is able to increase the growth of the upstream sector. It is followed by food, beverages, and tobacco, wood processing industry, LGA sector, non-mining mineral processing industry sector, transport and communication sector, paper industrial sector, printing, and publishing, as well as other services sectors. Recycling manufacturing sector has a weak backward linkage. Judging from the total index related to the forward purposes, there are seven sectors that have a high degree of sensitivity. Chemical industry, rubber, and plastics have thestrongest index. It means that the sectors have the greatest ability to promote the growth of it's downstream industrial sectors. Followed by the agricultural sector, trade, hotels and restaurants, transport and communication sectors,finance, leasing, and business services, wood processing industry, and non- mineral excavation manu-facturing sector. Recycling manufacturing sector still has the most vulnerable total index to the forward linkage. The results of this study further strengthen Handayani's research, 2006, who found that the manufacturing sector is the dominant sector in Indonesia. Based on the results of the environmental input-output analysis, as summarized in Table 1, it is known that the heaviest polluters to the environment of South Sulawesi in 
2010 is the chemical processing industry, rubber, plastic, basic metals processing industry, and industrial processing of metal goods.

Chemical processing industry, rubber, and plastics are the largest BOD water pollution effects production, amounted to 0.18. It means that in every one million increase in final demand in the chemical industry, rubber, and plastics will lead to the increase of water pollution load about $0.18 \mathrm{~kg}$ BOD. The three sectors are almost in all districts / cities in South Sulawesi. In Tana Toraja, industrial manufacture of essential oils / patchouli become the largest contributor to GDP, at IDR441.8 billion with the highest level of labor productivity, at IDR 24.5 billion / person. In the district of Bone, industrial manufacture of alcohol / spirits has the greatest investment value amounted IDR 14.6 billion with the highest level of labor productiviy, which amounted to IDR 186.7 million / person. In Luwu district, patchouli oil production industry also has the highest labor productivity, which amounted to IDR 400 million / person. Industrial processing of basic metals and metal goods industries such as the manufacture of packaging cans and drums, aluminum goods, machinery / equipment of agriculture and forestry, and printer equipment industries are the heaviest air polluters. Basic metals processing industry produces NO2 air pollution effects and the highest TSP: at 1.22 and 1.16. This implies that at each increase in the final demand for the basic metals processing industry of one million ruphias will lead to an increasing of NO2 air pollution loads and loads weighing 1.22 kilograms of air pollution TSP weighing 1.16 kilograms. Metal processing industry is the producer of the goods from the effects of SO2 air pollution and water pollution effects highest TSS: namely 1.32 and 5.52. This implies that for each increasing of final demand in the manufacturing sector of one million rupiah metal will lead to increasing of NO2 air pollution loads in weigh 1.32 kilograms and air pollution TSP in a weigh of 5.52 kilograms.

The impact of air pollution by Achmadi (1998) may cause respiratory tract irritation effects, weaken the lungs defense system, and potentially disrupt the cardiovascular / blood circulation system. Meanwhile, according to Schloz and Haffner (1992), air pollution can reduce the productivity of the soil (heavy metal contamination and increase in the acidity of the soil), cause metal corrosion, and paint damage, stones (marble and concrete). The safe industry to air and water environments in South Sulawesi is textile, apparel, and leather. The results of this research contradict with Kurniati's research (2005) for the case of the textile industry in South Sulawesi, on average still use Non-Weaving Machine Tools (handloom) and weaving Gedogan, so it does not produce waste contaminants that are harmful to the environment. By using the output data of the manufacturing sector and the coefficient of pollution cleaning cost, can be estimated about the cleaning cost of the air and water pollution caused by the presence of activity in the manufacturing sector in South Sulawesi. The required cost for the economy to clean the pollution obtained by multiplying the production of each output value of the manufacturing sector with the cleaning cost coefficient of pollution. The whole total value is the economic value of the amount of pollution generated by the entire manufacturing sector. Based on the calculations,showed that the value of environmental pollution that occurred in South Sulawesi is measured from the amount of pollution cleaning cost amounted to IDR 278.28 billion or equivalent to 2.8 percent of the total output of manufacturing sector. Judging from the class of pollution, air pollution NO2 is the pollution source which most requires cleaning cost, amounted to IDR 209.99 billion and water pollution BOD is the least pollution amounted to IDR 3.88 billion of cleaning cost. Chemical industry, rubber, and plastic is the biggest sector require cleaning cost, which amounted to IDR 36.85 billion. While the timber industry sector (excluding furniture) at least require the amounted to IDR 426.49 million of cleaning cost.

The results of these researches are almost similar with the results of Hussein's research (2007) who found that the proportion of the value of environmental pollution in seven African countries, including of Argeria, Egypt, Lebanon, Morocco, Syria, Tunisia, and Iran ranged from 2.1 to 7.4 percent of GDP. The number of regulations in the field of environment is increasing every year. This suggests that the increasingly stringent regulations are used to maintain and to improve the quality of the environment. These regulations are required upon the business activities in order to reduce or to decrease the destruction impact of environmental quality. The Data of growing amount of large and medium industries in South Sulawesi in 2007-2010 showed that the number of large and medium industries has decreased and the growth negative, so the impact on the value added. Given this reality, the case in South Sulawesi is closer to Haven's hypothesis, where the existence of the regulation are considered as obstacles to the advancement of small industry because the company will incur additional cost for pollution control. The relationship pattern between per capita income data and environmental pollution in South Sulawesi in 2002-2010 forms an ascending curve from the lower left to the upper right, as shown in Figure; 1. It means that there is a tendency to an increase of pollution in line with the increase of the income per capita. Based on the trends 
analysis by dividing the analysis into three time periods, it is known that the development from 2002 to 2004, providing a change in the amount of 1533.30 tons of emissions and an increase in per capita income, IDR 1,468 million, in order to obtain the slope of 1044.48 tons / million rupiah. The developments from 2005 to 2007, providing a change in the amount of 2045.04 tons of emissions and an increase in per capita income of IDR 2,015 million, in order to obtain the slope of 1014.1 tons / million ruphias. The developments from 2008 until 2010, providing a change in the amount of 2667.25 tons of emissions and an increase in per capita income of IDR 3.85 million, in order to obtain the slope of 692.79 tons / million ruphias. Judging from the previous development of the three time periods above, it can be concluded that the environmental pollution in South Sulawesi has increased along with the increase in per-capita income, but the slope / trend of diminishing returns. This indicates that there has been a change in environmental management in South Sulawesi towards better condition. This is supported by the role of BLHD of the Province of South Sulawesi since 2009 which providing guidance and intensive monitoring of a number of companies in South Sulawesi through Rating Performance Program in Environmental Management (PROPER).

\section{Conclusions and Recommendations}

This study shows that the sectors of the chemical processing industry, basic metals, and metal goods are the contributors to the pollution of the toughest environments in South Sulawesi in 2010, and the environmental problems that occur in South Sulawesi are more likely to approach the Haven's hypothesis. The Limitations of this study is to analyze the role of a new activity in the manufacturing sector so it can not show the overall role of economic activities to environmental contamination. This study is for an academic purpose, not intended for policy research. Based on the analysis of this study, it can be suggested for some of the following: 1) the manufacturing of furniture needs to obtain priority clearance because the sector is a sector that is relatively polluting the environment but the needs for cleaning cost are relatively low, 2) chemical processing industries, basic metals processing, and processing of metal goods production should be controlled because the industrial sector is a sector that causes severe pollution to the environment in South Sulawesi and relatively needs high cleaning cost, 3) data collection needs to be done intensively against pollution load/ emissions generated by all sectors of economic activity, and 4) Further research is expected to analyze the role of all sectors of economic activity to environmental contamination.

\section{References}

Achmadi, U. F. (1998). Dampak Polusi Udara terhadap Kesehatan. Dalam Himpunan Karangan Ilmiah di Bidang Perkotaan dan Lingkungan, 1.

Arsyad, L. (2010). Ekonomi Pembangunan Edisi ke-5. UPP STIM YKPN. Yogyakarta

Birdsall, N. \& Wheeler, D. (1993). Trade Policy and Industrial Pollution in Latin America: Where is The Pollution Haven? The Journal of Environment \& Development, 2(1), 137-149.

Grossman, G. M. \& Krueger, A. B. (1995). Economic Growth and the Environment. Quarterly Journal of Economics, 110, (3), 53-77.

Grossman, G. M. \& Krueger, A. B. (1991). Environmental Impact of a North American Free Trade Agreement. Working Paper 3914. National Bureau of Economic Research. Cambridge, MA.

Handayani, S. B. (2006). Analisis Ekonomi dan Lingkungan dengan Model I-O Modifikasi. Thesis UI.

Herman, K. (2007). Dampak Pesatnya Pengembangan Perkebunan Kakao terhadap Serangan Hama PBK, Lingkungan, dan Perekonomian Regional Sulawesi Selatan. Disertasi IPB. Bogor.

Hirschman, A. O. (1958). The Strategy of Economic Development. New Haven. Conn.: Yale University Press.

Hussein, M. A. (2007). Costs of Environmental Degradation, An Analysis in The Middle East and North Africa Region. Emerald, Management of Environmental Quality: An International Journal, 19(3), 305-317.

Kurniati, L. (2005). Input-Output Lingkungan Pada Sektor Industri Pengolahan dalam Menunjang Pembangunan Berkelanjutan di DKI Jakarta. Thesis UI.

Miller \& Blair. (1985). Input-Output Analysis: Foundations and Extensions. Prentice-Hall. Inc. Englewood Cliff. New Jersey.

Myrdal, G. (1957). Economic Theory and Underdeveloped Regions. London: University Paperbacks. Methuen.

Perroux, F. (1970). Aliénation et société industrielle. Paris. Gallimard. 185

Porter, M. E. \& Linde, C. D. (1995). Toward A New Conception of The Environment-competitiveness Relationship. Journal of Economic Perspectives, 9(4), 97-118.

Razak, A. R. (2009). Esensi Pembangunan Ekonomi Daerah. Nala Cipta Latera. Makassar.

Resosudarmo, L. (2000). Emisi Polusi Udara dan Air Sungai Dalam Struktur Industri Indonesia. PAU-UI. Jurnal Ekonomi Lingkungan, 11, 47-73. 
Rukmana, D. (2012). Ekonomi Lingkungan dan Sumber Daya Alam. Arus Timur. Makassar.

Schloz \& Haffner. (1992). Assessment of Potensial Risks Through Air Pollutants Caused by Energy Consumption for Java. Substitusi dari The Environmental Impacts of Energy Strategies for Indonesia Project. Riset Bersama BPPT dan Pusat Penelitian Nuklir Jerman. Shafik, Nemat. 1994. Economic Development and Environment Quality: An Econometric Analysis. Oxford Economic Papers, 46, 7, 57-77.

Suparmoko \& Suparmoko, M. R. (2000). Ekonomika Lingkungan. BPFE. Yogyakarta.

Annex:

Table 1: Economi c sectors in South Sulawesi, 2010

\begin{tabular}{clcc}
$\begin{array}{c}\text { Kode IO } \\
\text { (1) }\end{array}$ & \multicolumn{1}{c}{$\begin{array}{c}\text { Sectors } \\
\text { (2) }\end{array}$} & $\begin{array}{c}\text { BLj } \\
\mathbf{( 3 )}\end{array}$ & $\begin{array}{c}\text { FLi } \\
\mathbf{( 4 )}\end{array}$ \\
\hline 1 & Agricultural & 0,886 & 1,329 \\
2 & Mining and Excavation & 0,977 & 0,973 \\
3 & Food, Drinking, and Tobbaco & 1,356 & 0,913 \\
4 & Textile, apparel, \& leather & 0,825 & 0,806 \\
$5^{*}$ & Wood Processing (excluding furniture)* & 1,298 & 1,117 \\
6 & Paper, publication \& printing & 1,032 & 0,797 \\
7 & Chemical, rubber, \& plastic & 0,763 & 1,935 \\
$8^{*}$ & Entrenchment, not metal $*$ & 1,129 & 1,116 \\
9 & Basic metal & 0,853 & 0,872 \\
10 & Metal goods, machine/equipment & 0,738 & 0,842 \\
11 & Furniture \& other processing & 0,959 & 0,757 \\
12 & Recycle goods & 0,698 & 0,698 \\
13 & Electric, gas, dan water & 1,188 & 0,841 \\
14 & Constructions & 1,413 & 0,854 \\
15 & Trade, hotel, dan restaurant & 0,924 & 1,245 \\
$16^{*}$ & Transportations dan communications $*$ & 1,074 & 1,162 \\
17 & Finance, rent, \& firm services & 0,868 & 1,133 \\
18 & Other serveces & 1,019 & 0,780 \\
\hline
\end{tabular}

Source : Data processed , 2013

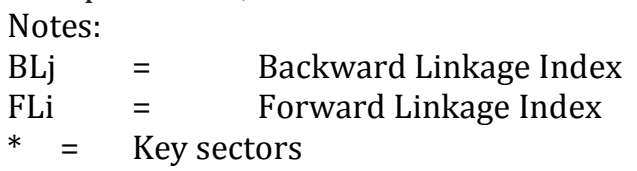

Table 2: The Calculation of Input-Output Environmental South Sulawesi Datas in 2010

\begin{tabular}{|c|c|c|c|c|c|c|c|c|c|c|}
\hline \multirow{2}{*}{$\begin{array}{l}\text { Analysis } \\
\text { Tools }\end{array}$} & \multirow{2}{*}{$\begin{array}{l}\text { Para } \\
\text { meter }\end{array}$} & \multicolumn{9}{|c|}{ The Manufacturing Sectors } \\
\hline & & 1 & 2 & 3 & 4 & 5 & 6 & 7 & 8 & 9 \\
\hline \multirow{4}{*}{$E_{i}^{P}$} & $\mathrm{SO}_{2}$ & 0,0799 & 0,0489 & 0,0526 & 0,0851 & 0,4115 & 0,2612 & 0,3171 & $1,3207^{*}$ & 0,0402 \\
\hline & $\mathrm{NO}_{2}$ & 0,0537 & 0,0344 & 0,0990 & 0,0568 & 0,2683 & 0,2104 & $1,2240 *$ & 0,2222 & 0,0250 \\
\hline & TSP & 0,0560 & 0,0230 & 0,1222 & 0,1322 & 0,1282 & 0,0856 & $1,1559 *$ & 0,1819 & 0,0110 \\
\hline & BOD & 0,0479 & 0,0069 & 0,0037 & 0,0007 & $0,1815^{*}$ & 0,0212 & 0,0030 & 0,0705 & 0,0005 \\
\hline \multirow{6}{*}{$I E_{i}^{P}$} & TSS & 0,0518 & 0,0194 & 0,0732 & 0,0042 & 0,6444 & 0,1612 & 0,1376 & $5,5246^{*}$ & 0,1171 \\
\hline & $\mathrm{SO}_{2}$ & 0,27 & 0,17 & 0,18 & 0,29 & 1,41 & 0,90 & 1,09 & $4,54^{*}$ & 0,14 \\
\hline & $\mathrm{NO}_{2}$ & 0,22 & 0,14 & 0,41 & 0,23 & 1,10 & 0,86 & $5,02^{*}$ & 0,91 & 0,10 \\
\hline & TSP & 0,27 & 0,11 & 0,58 & 0,63 & 0,61 & 0,41 & $5,49 *$ & 0,86 & 0,05 \\
\hline & BOD & 1,28 & 0,19 & 0,10 & 0,18 & $4,86^{*}$ & 0,57 & 0,08 & 1,89 & 0,01 \\
\hline & TSS & 0,07 & 0,03 & 0,10 & 0,01 & 0,86 & 0,22 & 0,18 & $7,38^{*}$ & 0,16 \\
\hline \multirow{4}{*}{$I M_{i}^{P}$} & $\mathrm{SO}_{2}$ & 0,93 & 0,93 & $1,73^{*}$ & 0,90 & 1,07 & 0,85 & 0,95 & 0,80 & 0,85 \\
\hline & $\mathrm{NO}_{2}$ & 0,98 & 0,94 & $1,44^{*}$ & 0,92 & 1,22 & 0,90 & 0,86 & 0,84 & 0,88 \\
\hline & TSP & 0,89 & 0,94 & 1,18 & 0,80 & $1,59 *$ & 1,07 & 0,79 & 0,78 & 0,97 \\
\hline & BOD & 0,55 & 0,56 & 0,77 & $2,50 *$ & 0,54 & 0,52 & 1,76 & 0,50 & 1,30 \\
\hline \multirow{4}{*}{$I E_{j}^{C}$} & TSS & 0,29 & 0,36 & 1,50 & $4,90^{*}$ & 0,27 & 0,27 & 0,97 & 0,23 & 0,23 \\
\hline & $\mathrm{SO}_{2}$ & 0,18 & 0,23 & 0,22 & 1,06 & 1,21 & 0,58 & $3,89 *$ & 0,95 & 0,69 \\
\hline & $\mathrm{NO}_{2}$ & 0,11 & 0,10 & 0,18 & 0,01 & 0,22 & 0,14 & $8,05^{*}$ & 0,08 & 0,10 \\
\hline & TSP & 0,23 & 0,62 & 0,02 & 0,05 & $4,35^{*}$ & 2,09 & 0,11 & 0,82 & 0,02 \\
\hline
\end{tabular}




\begin{tabular}{lllllllllll} 
& BOD & 0,89 & 0,65 & 0,02 & 0,04 & $4,35^{*}$ & 2,09 & 0,11 & 0,82 & 0,02 \\
& $\mathrm{TSS}$ & 0,05 & 0,10 & 0,62 & 0,01 & 0,78 & 0,58 & 0,09 & 2,53 & $4,23^{*}$ \\
& $\mathrm{SO}_{2}$ & 0,62 & 0,59 & $4,45^{*}$ & 0,52 & 0,74 & 0,56 & 0,52 & 0,51 & 0,50 \\
$I^{C} M_{j}^{C}$ & $\mathrm{NO}_{2}$ & 0,15 & 0,13 & $7,15^{*}$ & 0,21 & 0,57 & 0,23 & 0,12 & 0,33 & 0,12 \\
& $\mathrm{TSP}$ & 0,83 & 0,74 & $2,29^{*}$ & 0,74 & 1,34 & 0,92 & 0,73 & 0,70 & 0,71 \\
& $\mathrm{BOD}$ & 0,21 & 0,21 & 0,74 & $5,02^{*}$ & 0,23 & 0,19 & 1,86 & 0,20 & 0,35 \\
& $\mathrm{TSS}$ & 0,07 & 0,07 & $4,41^{*}$ & 4,10 & 0,06 & 0,04 & 0,18 & 0,04 & 0,04 \\
& $\mathrm{SO}_{2}$ & 1,51 & 1,58 & 0,39 & 1,74 & 1,44 & 1,50 & 1,82 & 1,57 & $1,71^{*}$ \\
$\hat{M}_{i}$ & $\mathrm{NO}_{2}$ & 6,52 & 7,52 & 0,20 & 4,33 & 2,16 & 3,95 & 7,48 & 2,52 & $7,59^{*}$ \\
& $\mathrm{TSP}$ & 1,08 & 1,27 & 0,52 & 1,08 & 1,18 & 1,16 & 1,08 & 1,11 & $1,36^{*}$ \\
& $\mathrm{BOD}$ & 2,56 & 2,74 & 1,04 & 0,50 & 2,37 & 2,72 & 0,95 & 2,48 & $3,71^{*}$ \\
& $\mathrm{TSS}$ & 3,84 & 5,06 & 0,34 & 1,19 & 4,84 & 6,37 & 5,46 & 6,45 & $6,62^{*}$ \\
& $\mathrm{SO} 2$ & 0,05 & 0,04 & 0,04 & 0,31 & 1,71 & 0,52 & $4,24^{*}$ & 4,34 & 0,10 \\
$\hat{E}_{i}$ & $\mathrm{NO} 2$ & 0,02 & 0,01 & 0,07 & 0,00 & 0,24 & 0,12 & $40,40^{*}$ & 0,08 & 0,01 \\
& $\mathrm{TSP}$ & 0,06 & 0,07 & 0,14 & 0,24 & 0,32 & 0,12 & $27,60^{*}$ & 1,25 & 0,01 \\
& $\mathrm{BOD}$ & 1,15 & 0,12 & 0,00 & 0,00 & $21,13^{*}$ & 1,19 & 0,01 & 1,55 & 0,00 \\
& $\mathrm{TSS}$ & 0,00 & 0,00 & 0,06 & 0,00 & 0,67 & 0,13 & 0,02 & $18,67^{*}$ & 0,66 \\
\hline
\end{tabular}

Source : Data processed , 2013

Table 3: Economic Value of Pollution in Manufacturing Sectors in South Sulawesi, 2010 (IDR billion)

\begin{tabular}{|c|c|c|c|c|c|}
\hline Manufacturing Sectors & $\mathrm{SO}_{2}$ & & & & \\
\hline (1) & (2) & (3) & (4) & (5) & (6) \\
\hline 1. Food, Drinking, and Tobbaco & $3.218,99$ & $10.949,72$ & 713,07 & 635,43 & 470,43 \\
\hline 2. Textil, apparel, $\varepsilon$ & 401,09 & $1.154,64$ & 195,99 & 44,20 & 90,97 \\
\hline $\begin{array}{l}\text { 3. Wood Processing (excluding } \\
\text { furniture)* }\end{array}$ & 178, & 129,27 & 86,51 & 1,49 & 31,57 \\
\hline 4. Paper, publication \& printing & 1.58 & 74,35 & 93, & 0,09 & 0,17 \\
\hline 5. Chem & $17.718,36$ & $5.879,09$ & 970,73 & 826,20 & $.454,89$ \\
\hline 6. Entrenchment, not metal * & $2.289,30$ & $1.939,14$ & 160,66 & 330,47 & $1.899,05$ \\
\hline 7. Basic metal & $14.570,54$ & $39.362,30$ & $3.076,74$ & 1,58 & 60,52 \\
\hline 8. Metal goods, & $1.507,35$ & 279,40 & 377,12 & 44,38 & $3.542,39$ \\
\hline 9. Fur & 269,71 & 219,82 & 14,59 & 0,15 & $1.431,88$ \\
\hline & 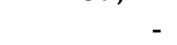 & - & - & - & - \\
\hline Total $=278.284,32$ & $41.742,21$ & $209.987,73$ & $5.688,52$ & $3.883,99$ & $16.981,87$ \\
\hline
\end{tabular}

Source : Data processed , 2013

Figure 1: The Development of Pollution Margin against South Sulawesi Per Capita 2002-2010

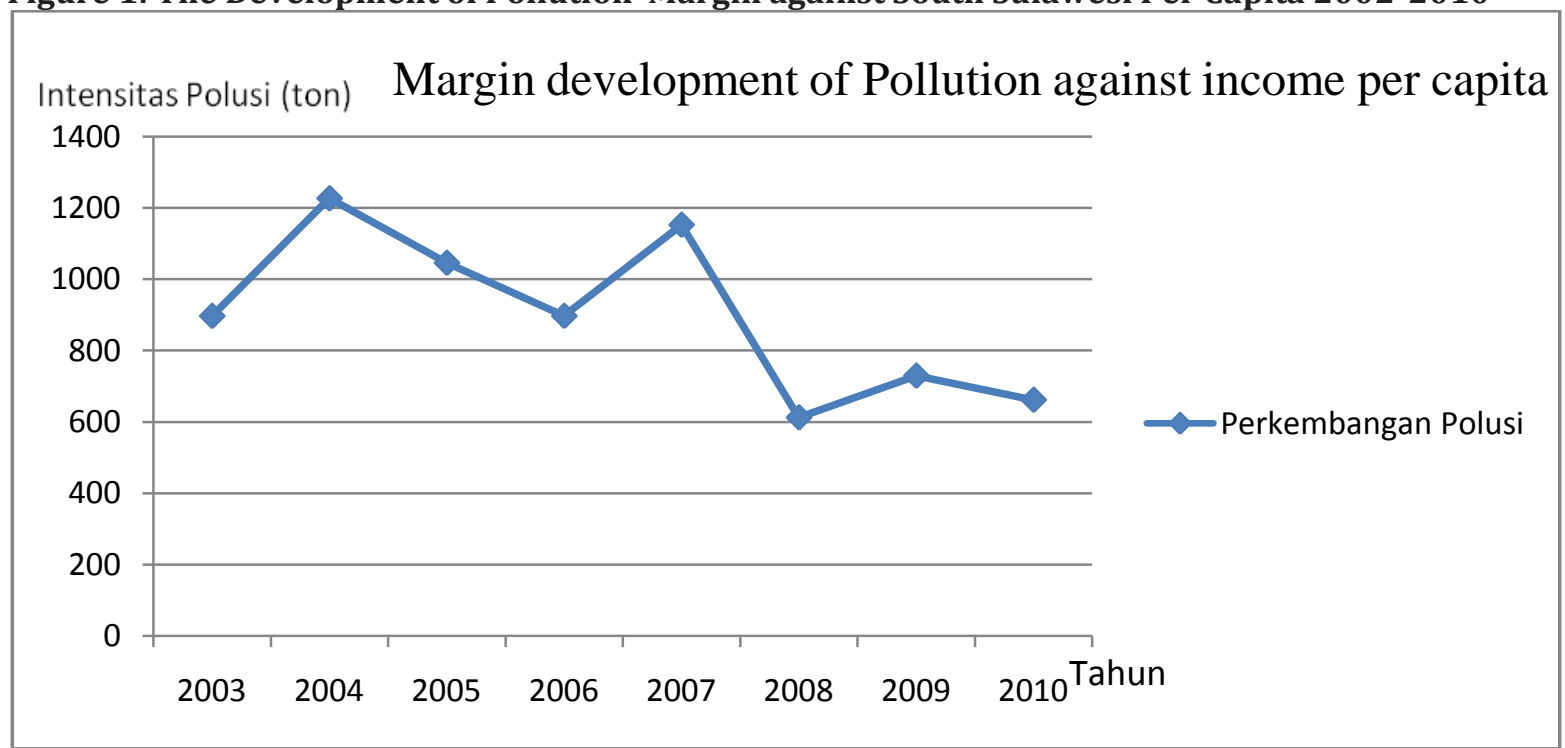

Source : Data processed , 2013 